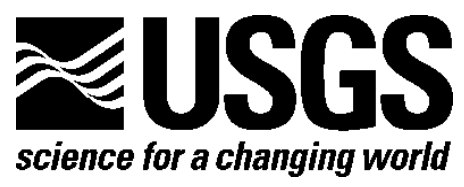

\title{
The 1946 Unimak Tsunami Earthquake Area: Revised Tectonic Structure in Reprocessed Seismic Images and a Suspect Near-Field Tsunami Source
}

By John J. Miller, Roland von Huene, and Holly Ryan

Open-File Report 2014-1024

U.S. Department of the Interior

U.S. Geological Survey 


\section{U.S. Department of the Interior \\ SALLY JEWELL, Secretary}

\section{U.S. Geological Survey \\ Suzette M. Kimball, Acting Director}

U.S. Geological Survey, Reston, Virginia: 2014

For more information on the USGS—-the Federal source for science about the Earth,

its natural and living resources, natural hazards, and the environment-visit

http://www.usgs.gov or call 1-888-ASK-USGS

For an overview of USGS information products, including maps, imagery, and publications, visit $h$ ttp://www.usgs.gov/pubprod

To order this and other USGS information products, visit http://store.usgs.gov

Suggested citation:

Miller, J.J., von Huene, Roland, and Ryan, H.F., 2014, The 1946 Unimak Tsunami Earthquake AreaRevised tectonic structure in reprocessed seismic images and a suspect near field tsunami source: U.S. Geological Survey Open-File Report 2014-1024, 19 p., http://dx.doi.org/10.3133/ofr20141024.

ISSN 2331-1258 (online)

Any use of trade, product, or firm names is for descriptive purposes only and does not imply endorsement by the U.S. Government.

Although this report is in the public domain, permission must be secured from the individual copyright owners to reproduce any copyrighted material contained within this report. 


\section{Contents}

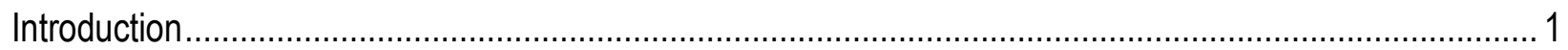

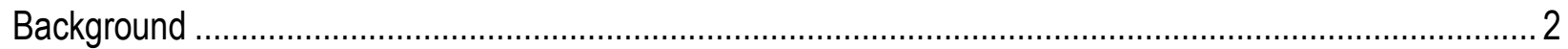

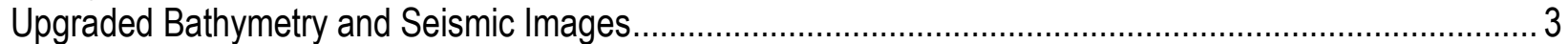

Seismic Images, High-Resolution Graphics Files, and SEG-Y Format Processed Data Files ................... 4

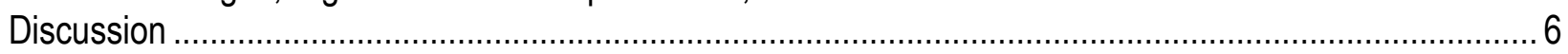

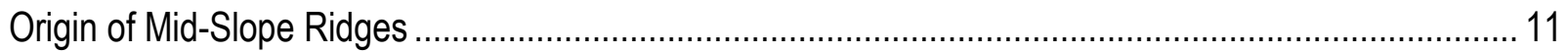

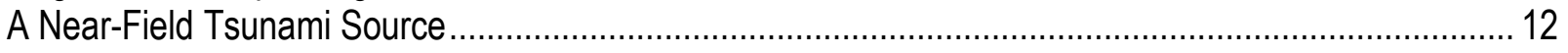

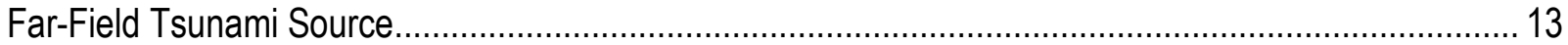

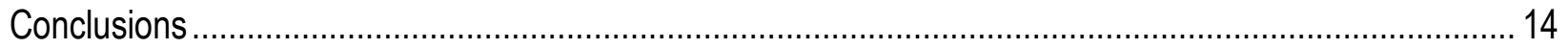

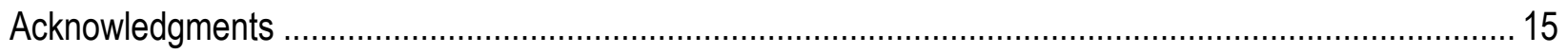

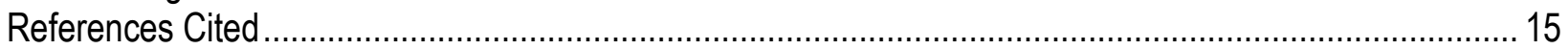

\section{Figures}

Figure 1. Unimak margin bathymetric compilation (Lim and others, 2011) from Unimak Pass to the

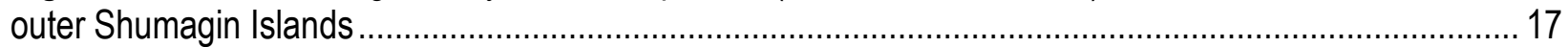

Figure 2. Multibeam bathymetry acquired with RV Ravelle (Rathburn and others, 2009) showing slope morphology in greater detail.

Figure 3. Perspective diagram of the bathymetry in figure 2 looking along the margin toward the northeast.

Figure 4. Large-scale bathymetry of Lone Hill from the RV Ravelle survey showing the escarpment from which it probably derived.

\section{Tables}

Table 1. Data acquisition and processing parameters for S.P. Lee (Lines 203, 205, 207) and RV Ewing (Lines 1235, 1237)

Table 2. Seismic images of the five seismic lines used in this report............................................... 6

\section{Conversion Factors}

Inch/Pound to SI

\begin{tabular}{lcl}
\hline \multicolumn{1}{c}{ Multiply } & \multicolumn{1}{c}{ By } & \multicolumn{1}{c}{ To obtain } \\
\hline & Volume & \\
\hline cubic inch $\left(\mathrm{in}^{3}\right)$ & 16.39 & cubic centimeter $\left(\mathrm{cm}^{3}\right)$ \\
cubic inch $\left(\mathrm{in}^{3}\right)$ & 0.01639 & cubic decimeter $\left(\mathrm{dm}^{3}\right)$ \\
cubic inch $\left(\mathrm{in}^{3}\right)$ & 0.01639 & liter $(\mathrm{L})$ \\
\hline
\end{tabular}

SI to Inch/Pound

\begin{tabular}{lll}
\hline \multicolumn{1}{c}{ Multiply } & By & \multicolumn{1}{c}{ To obtain } \\
\hline meter $(\mathrm{m})$ & Length & \\
kilometer $(\mathrm{km})$ & 3.281 & foot $(\mathrm{ft})$ \\
kilometer $(\mathrm{km})$ & 0.6214 & mile $(\mathrm{mi})$ \\
meter $(\mathrm{m})$ & 0.5400 & mile, nautical $(\mathrm{nmi})$ \\
\hline & 1.094 & yard $(\mathrm{yd})$ \\
\hline meter per second $(\mathrm{m} / \mathrm{s})$ & Flow rate & \\
\hline
\end{tabular}




\section{The 1946 Unimak Tsunami Earthquake Area: Revised Tectonic Structure in Reprocessed Seismic Images and a Suspect Near-Field Tsunami Source}

By John J. Miller ${ }^{1}$, Roland von Huene ${ }^{2}$, and Holly Ryan ${ }^{3}$

\section{Introduction}

A tsunami that was generated off Unimak Island at the western end of the Alaskan Peninsula in 1946 damaged Pacific coastal areas from Alaska to Antarctica. Its 42-meter (m) runup at Scotch Cap, Unimak Island, destroyed the lighthouse there. In the Hawaiian Islands, it took 159 lives and caused 26 million dollars of property damage; the tsunami similarly damaged island facilities across the south Pacific and destroyed a hut on the coast of Antarctica (Fryer and Tryon, 2005). The tsunami magnitude was 9.3 (Abe, 1979) which is comparable to the magnitude 9.1 tsunami (Ide and others, 2011) that devastated the populated Tohoku coast of Japan in 2011. The epicenter of the causative 1946 earthquake occurred in the shallow reaches of the Aleutian subduction zone, and its surrounding aftershocks were mostly beneath the slope between Unimak Pass and Sanak Island (fig. 1) (Lopéz and Okal, 2006). As pointed out by Kanamori (1972), the earthquake was a charter member in the "tsunami" earthquake category that produced an outsized wave compared to its quake magnitude. Despite several expeditions to the area and multiple seismological studies, the mechanics of this event are still controversial (Kanamori, 1972; Johnson and Satake, 1997; Okal and others, 2002, 2003; Fryer and others, 2004; Lopéz and Okal, 2006). Conceivably, the 1946 earthquake produced the far-field tsunami by tectonic seafloor displacement, but the near-field tsunami is inferred to be sourced by a large landslide (Okal and Herbert, 2007). However, a causative landslide was not identified (Rathburn and others, 2009) during the latest expedition there, and if a proposed accretionary prism is located in the epicenter area (Lewis and others, 1988), this would be an unlikely location for an Mw 8.6 earthquake. The most controversial issue revolves around a possible source large enough to generate the high runup observed along the Unimak coast (Okal and others, 2003).

This report adds to the database of information available to study this problem by (1) reprocessing two multichannel reflection seismic lines acquired with RV Ewing (cruise EW9409, 1994, http://www.ig.utexas.edu/sdc/cruise.php? cruiseIn=ew9409) that are spaced 250 kilometers $(\mathrm{km})$ apart through post-stack time migration + depth conversion (Line 1235) and through prestack depth migration (Line 1237), and (2) reprocessing three 30 (or more) year (yr) old U.S. Geological Survey (USGS) seismic lines (cruise L-12-82-WG, 1982, http://walrus.wr.usgs.gov/infobank/l/l1282wg/html/l-12-82-wg.meta.html) located between the two Ewing lines through post-stack time migration + depth conversion (fig. 1). Much of the seismic data were located in a limited area of multibeam bathymetry. The two lines surveyed with the RV Ewing were acquired with seismic reflection systems including an 8,400 cubic inch

\footnotetext{
${ }^{1}$ U.S. Geological Survey, Denver, Colo.

${ }^{2}$ U.S. Geological Survey, Scientist Emeritus, Diamond Springs, Calif.

${ }^{3}$ U.S. Geological Survey, Scientist Emeritus, Menlo Park, Calif.
} 
$\left(\mathrm{in}^{3}\right)$ seismic source that was much more powerful than the older USGS acquisition systems that had a 1,350 $\mathrm{in}^{3}$ source. These data have been presented previously as small scale line drawing interpretations in a study of Alaska margin earthquake rupture segmentation (von Huene and others, 2012). This report presents the entire seismic images. In addition, comparison of the geology across the 2011 Tohoku tsunami area margin shows the structural similarity of the 1946 Unimak Island-Scotch Cap and Tohoku regions.

This online publication also provides the means to download high-resolution graphic images of all five seismic lines in jpeg format as well as to download the processed seismic data in standard, Society of Exploration Geophysicists Y format (SEG-Y, Barry and others, 1975).

\section{Background}

The 1946 Unimak earthquake occurred along the plate margin off Unimak Island in an unusually structured region that transitions from the Alaska to the Aleutian convergent margin system. Unimak Island is part of the Alaskan continent that is geographically part of the Alaska Peninsula landmass, but separated from it by a narrow marine passage (fig. 1). On its Pacific side, Sanak Island is located about midway on the Unimak continental shelf. Seaward (south of the shelf, is a steep upper continental slope that flattens into a roughly $50 \mathrm{~km}$ wide mid-slope terrace. The rough outer edge of the terrace drops off steeply across the rugged lower slope and into the 6-km-deep Alaska-Aleutian Trench axis (figs. 1 and 2). This continental margin was first studied comprehensively by Bruns and others (1987) using seismic data acquired in 198081 with the USGS vessel S.P. Lee and processed to stacked time sections (cruises Lee, 1981 and 1982, L8-81-WG, and L-12-82-WG). Surprisingly, they found a margin dominated by extensional rather than contractile deformation. Only the lower slope displayed contractile structure that was most obviously imaged in the frontal sediment prism.

Two unusual features of the Unimak margin are: (1) the oblique trending Sanak Basin and associated ridge supporting Sanak Island, and (2) a 200-km-long series of ridges including Unimak Seamount on the mid-slope terrace (Bruns and others, 1987). The oblique-trending structures are inherited tectonic features that were contiguous with the Beringian margin until Eocene time when the Aleutian island arc propagated from the bend in the Beringian margin. The structures are located at the division between the Aleutian island arc to the west and the Alaskan continental arc. Another feature, ridges on the mid-slope terrace, are up to 2,200 $\mathrm{m}$ high and parallel the margin's trend west of Unimak Seamount (figs. 1, 2, and 3). Prior to the last decade, their morphology was largely inferred by connecting widely spaced conventional bathymetric transects, and the widely spaced data were contoured as a single feature (Bruns and others, 1987).

Despite seismic images that were degraded by instrument failure during recording, it was clear that the sediment section imaged on the shelf extended downslope to within about $25 \mathrm{~km}$ or less of the trench. The ages of strata on the Unimak shelf were inferred from regional stratigraphy of the Alaska Trench margin along the Kodiak shelf where industry drilling provided dates (Bruns and others, 1987). Seismic-image character, unconformities, and wideangle seismic velocities of the Kodiak shelf are similar to those of the Unimak shelf. Both sediment sections are inferred to rest on Cretaceous metamorphic rock and Paleogene intrusions with a relatively high seismic velocity like those exposed on the islands. Therefore, the acoustic basement of metamorphic rock was assumed to represent the acoustic basement that is imaged close to the frontal prism.

Unimak Seamount and the ridges on the mid-slope terrace are present along-margin for about $200 \mathrm{~km}$ from the area seaward of Sanak Island to Unimak Pass (fig. 1). A dredge haul from Unimak Seamount included, among a variety of calcareous and silicic sediment, two samples of 
Eocene-aged island arc basalt. The 2-km-high seamount was interpreted as the exposure of a failed volcanic mass that had been block faulted within a subsiding framework structure (Bruns and others, 1987). The entire Unimak Ridge was assumed to be composed of volcanic rock; at the time, this assumption was supported by the lack of strata in the seismic images across the ridge and by a positive magnetic anomaly.

Location of the epicenter and aftershocks from the 1946 earthquake were recomputed (Lopéz and Okal, 2006), and a larger earthquake than previously described was interpreted from seismology and tsunami analysis (Okal, oral commun., 2009). When plotted on current bathymetry, the aftershocks are concentrated on the Unimak margin slope and around Unimak Ridge (fig. 1). The rupture area estimated from aftershocks measured $200 \mathrm{~km}$ by $120 \mathrm{~km}$ (fig. 1; Okal and Hebert, 2007).

RV Ewing seismic reflection images (von Huene and others, 2012) indicated a narrower width of the accretionary prism than previously assumed (Lewis and others, 1988). The images showed upper-slope strata truncated from mass wasting and slump masses farther downslope. Interpretation of these seismic images benefited greatly from the morphology shown in current bathymetric compilations (Rathburn and others, 2009; Lim and others, 2011).

\section{Upgraded Bathymetry and Seismic Images}

In the past 25 (plus) yr since the USGS study of the Unimak-Sanak margin was conducted (Bruns and others, 1987), patches of multibeam bathymetry were acquired on various cruises (Fryer and Tryon, 2005; Flueh and von Huene, 1994). These data were included in a regional map of the Alaska offshore area that combined separate multibeam surveys (fig. 1; Lim and others, 2011). In particular, the resolution of Unimak mid-slope ridge morphology on a kilometer scale shows segmentation of the ridge and Unimak Seamount not seen from sparse data available previously (figs. 2 and 3). The mid-slope ridges are here designated from east to west: (1) Unimak Seamount (U SMT, fig. 1), a 30-km-long ridge containing the officially named Unimak Seamount; (2) Unimak Ridge, a 50-km-long ridge with a sharply pointed crest; and (3) separated from this ridge, an isolated hill (here informally called Lone Hill) that is up to $15 \mathrm{~km}$ wide and $800 \mathrm{~m}$ high. Landward of the mid-slope terrace, the upper slope is cut by many normal faults with modest vertical displacement. In the area off Unimak Island, the upper slope has unusually straight canyons and indicators of mass wasting such as small slide scars. The diagonal-trending Sanak Island Basement Ridge and Basin extend down the upper slope where they bend to become sub-parallel to the regional trend. Aftershocks of the 1946 earthquake are concentrated in this regional structural transition that dominates the Unimak margin (fig. 1). This ridge is a segment boundary for the 1946 earthquake.

Reprocessed seismic images, through application of processing techniques improved over $30 \mathrm{yr}$, show structural detail not seen in the 1980s images of the USGS data. The updated geophysical information eliminates a number of apparent inconsistencies in previous interpretations of the Unimak margin geology. Improved resolution of strata reveals more faults and additional structure in the underlying acoustic basement. The basement generally has seismic velocities above 4 kilometers per second $(\mathrm{km} / \mathrm{s})$ (Bruns and others, 1987; Lizerralde and others, 2002). Comparison of the two RV Ewing seismic reflection transects (Line 1237 extending south-southeast from Unimak Pass and Line 1235 extending south from the Shumagin Islands) shows structural changes between the Alaska and Aleutian margins (von Huene and others, 2012). These images are $250 \mathrm{~km}$ apart. Combined with the newly reprocessed USGS seismic images inset into the composite bathymetric map, the images fill a former information gap.

In the 1980s, USGS seismic-reflection data were acquired using the following acquisition

parameters: 1,320 $\mathrm{in}^{3}$ airgun array; $2.4 \mathrm{~km}, 24$-channel array; $50 \mathrm{~m}$ shotpoint interval. These 
parameters provided a 50-m common depth point (CDP) interval at 24 -fold multiplicity. The data shown here had not been migrated prior to this study. The recent reprocessing through post-stack time migration followed by depth conversion was done at the USGS in Denver using a ProMAX2D; Version 2003.19.1 system. Complete data acquisition and processing parameters are given in table 1 . The RV Ewing acquisition parameters were: a roughly 8,400 in ${ }^{3}$ airgun array; a 4-km, 160-channel array; 50-m shotpoint interval. These parameters provided a $12.5 \mathrm{~m}$ CDP interval at 40-fold multiplicity. The increased data density resulted in much better spatial resolution and the more powerful source provided deeper penetration compared to the USGS data. The 1946 epicenter of Lopéz and Okal (2006) plotted on a bathymetric map, is located above a projected area of acoustic basement in the adjacent seismic images (fig. 1; table 2) or beneath the seaward end of the continental framework rather than the accretionary prism. Resolution of the previous Unimak mid-slope ridge is segmented on a roughly 1-km scale resolution and shows separation of Unimak Seamount, the Unimak Ridge, and Lone Hill. The updated geophysical information eliminates the interpreted continuity between rock of Unimak Seamount and the Unimak Ridge geology.

The terminology applied here is that of an eroded margin with an accreted frontal prism. The term "margin framework" refers to upper-plate sections composed of rock structured like that beneath the shelf and on land. Covering this rock are sediments that have minor deformation from contractile forces originating along the plate interface. Improved resolution of strata in the underlying acoustic basement reveals local structure. The Alaska margin commonly has a "margin framework" that extends from the shelf downslope to the frontal prism (von Huene and others, 2012).

\section{Seismic Images, High-Resolution Graphics Files, and SEG-Y Format Processed Data Files}

Images of the five seismic lines used in this report, both uninterpreted and interpreted, are given in table 2 . Below each pair of images, we describe a few of the major features that are indicated with form lines in the graphics allowing the reader to study the electronic images in greater detail. In addition, each line provides two links to view both uninterpreted and interpreted images in high resolution or to download the high-resolution files in jpeg format. A third link allows the reader to download the processed seismic data in SEG-Y format (Barry and others, 1975). 
Table 1. Data acquisition and processing parameters for S.P. Lee (Lines 203, 205, 207) and RV Ewing (Lines $1235,1237)$. Note that the Ewing Line 1237 was processed using a pre-stack depth migration routine. The other four lines were processed through post-stack time migration and then converted to depth.

$\left[\mathrm{in}^{3}\right.$, cubic inches; $\mathrm{m}$, meters; CDP, common depth point; ms, milliseconds; AGC, automatic gain control; km, kilometers; hz, hertz; km/s, kilometers per second; NMO, Normal move out; SQRT, square root; >, greater than].

\begin{tabular}{|c|c|c|}
\hline \multicolumn{2}{|l|}{ Recording Parameter } & RV Ewing \\
\hline Year recorded & $1980-1981$ & 1994 \\
\hline Energy source & $1,320 \mathrm{in}^{3}$ airgun array & $8,400 \mathrm{in}^{3}$ airgun array \\
\hline Source interval & $50 \mathrm{~m}$ & $50 \mathrm{~m}$ \\
\hline Streamer length & $2,400 \mathrm{~m}$ & $4,000 \mathrm{~m}$ \\
\hline Number of channels & 24 & 160 \\
\hline Group interval & $100 \mathrm{~m}$ & $25 \mathrm{~m}$ \\
\hline Near/far offsets & $296 / 2,596 \mathrm{~m}$ & $225 / 4,200 \mathrm{~m}$ \\
\hline CDP fold & 24 & 40 \\
\hline \multicolumn{3}{|c|}{ Processing Flow and Parameters } \\
\hline S.P. Lee & \multicolumn{2}{|c|}{ RV Ewing } \\
\hline Scaling: $500 \mathrm{~ms} \mathrm{AGC}$ & \multicolumn{2}{|c|}{ Bandpass Filter: 8-70 hz Butterworth } \\
\hline $\begin{array}{l}\text { Deconvolution: Spiking; single window } \\
\text { design; } 160 \mathrm{~ms} \text { filter length }\end{array}$ & \multicolumn{2}{|c|}{ Scaling: $500 \mathrm{~ms}$ AGC } \\
\hline Scaling: $500 \mathrm{~ms}$ AGC & \multicolumn{2}{|c|}{ F-K Filter: Eliminate linear noise trains in shot domain } \\
\hline $\begin{array}{l}\text { Velocity analysis: semblance and constant } \\
\text { velocity stacks at } 2.5-5 \mathrm{~km} \text { intervals }\end{array}$ & \multicolumn{2}{|c|}{ Deconvolution: spiking; single window design; $200 \mathrm{~ms}$ filter length } \\
\hline $\begin{array}{l}\text { NMO and stacking; 1/SQRT(fold) mute } \\
\text { compensation }\end{array}$ & \multicolumn{2}{|l|}{ Scaling: $300 \mathrm{~ms} \mathrm{AGC}$} \\
\hline $\begin{array}{l}\text { Velocity manipulation: smooth velocity } \\
\text { model over } 101 \text { CDPs and } 200 \mathrm{~ms} \text {; output at } \\
2.5 \mathrm{~km} \text { interval }\end{array}$ & \multicolumn{2}{|c|}{$\begin{array}{l}\text { Velocity analysis: Semblance and constant velocity stacks at } 1.25-5 \\
\mathrm{~km} \text { intervals depending upon structure and signal strength. }\end{array}$} \\
\hline Post-stack migration: Stolt F-K algorithm & Line 1235 & Line 1237 \\
\hline Bandpass filter: $10-55 \mathrm{hz}$ Butterworth & $\begin{array}{l}\text { Automatic velocity picking: } \\
\text { velocities picked at } 5 \text { CDP } \\
\text { interval using hand-above } \\
\text { velocity model as a pilot. }\end{array}$ & $\begin{array}{l}\text { NMO and stacking: } 1 / \mathrm{SQRT} \text { (fold) } \\
\text { mute compensation* }\end{array}$ \\
\hline \multirow[t]{5}{*}{$\begin{array}{l}\text { Depth conversion: Velocity model used } \\
\text { was that used for migration }\end{array}$} & $\begin{array}{l}\text { NMO and stacking: } \\
\text { 1/SQRT(fold) mute } \\
\text { compensation }\end{array}$ & $\begin{array}{l}\text { Velocity manipulation: Smooth } \\
\text { velocity model over } 201 \mathrm{CDPs} \text { and } \\
300 \mathrm{~ms} \text {; output at } 2.5 \mathrm{~km} \text { interval } \\
\text { Convert RMS velocities to Interval; } \\
\text { edit to remove unreasonable values } \\
\text { (inversions, values }>6,000 \mathrm{~m} / \mathrm{s} \text {, etc.) }\end{array}$ \\
\hline & $\begin{array}{l}\text { Velocity manipulation: } \\
\text { Smooth velocity model over } \\
101 \mathrm{CDPs} \text { and } 200 \mathrm{~ms} \text {; output } \\
\text { at } 2.5 \mathrm{~km} \text { interval }\end{array}$ & $\begin{array}{l}\text { Pre-stack depth migration: } \\
\text { Common-offset domain }\end{array}$ \\
\hline & $\begin{array}{l}\text { Post-stack migration: Stolt } \\
\text { F-K algorthim }\end{array}$ & $\begin{array}{l}\text { Stacking: } 1 / \mathrm{SQRT} \text { (fold) mute } \\
\text { compensation }\end{array}$ \\
\hline & $\begin{array}{l}\text { Bandpass filter: } 10-55 \mathrm{hz} \\
\text { Butterworth filter }\end{array}$ & Scaling: $1,000 \mathrm{~m} \mathrm{AGC}$ \\
\hline & $\begin{array}{l}\text { Depth conversion: Velocity } \\
\text { model used was that used for } \\
\text { migration }\end{array}$ & $\begin{array}{l}* \text { post-stack time migration, using } \\
\text { parameters similar to those of Line } \\
1235, \text { was performed as a quality } \\
\text { check prior to pre-stack depth } \\
\text { migration. }\end{array}$ \\
\hline
\end{tabular}


Table 2. Seismic images of the five seismic lines used in this report. Top: uninterpreted; Bottom: interpreted with simple form lines. Two links below each interpreted image provide the means to view the images in high resolution or to download the high-resolution file in jpeg-format. A third link allows the reader to download the processed seismic data in SEG-Y format. VE, Vertical Exaggeration.
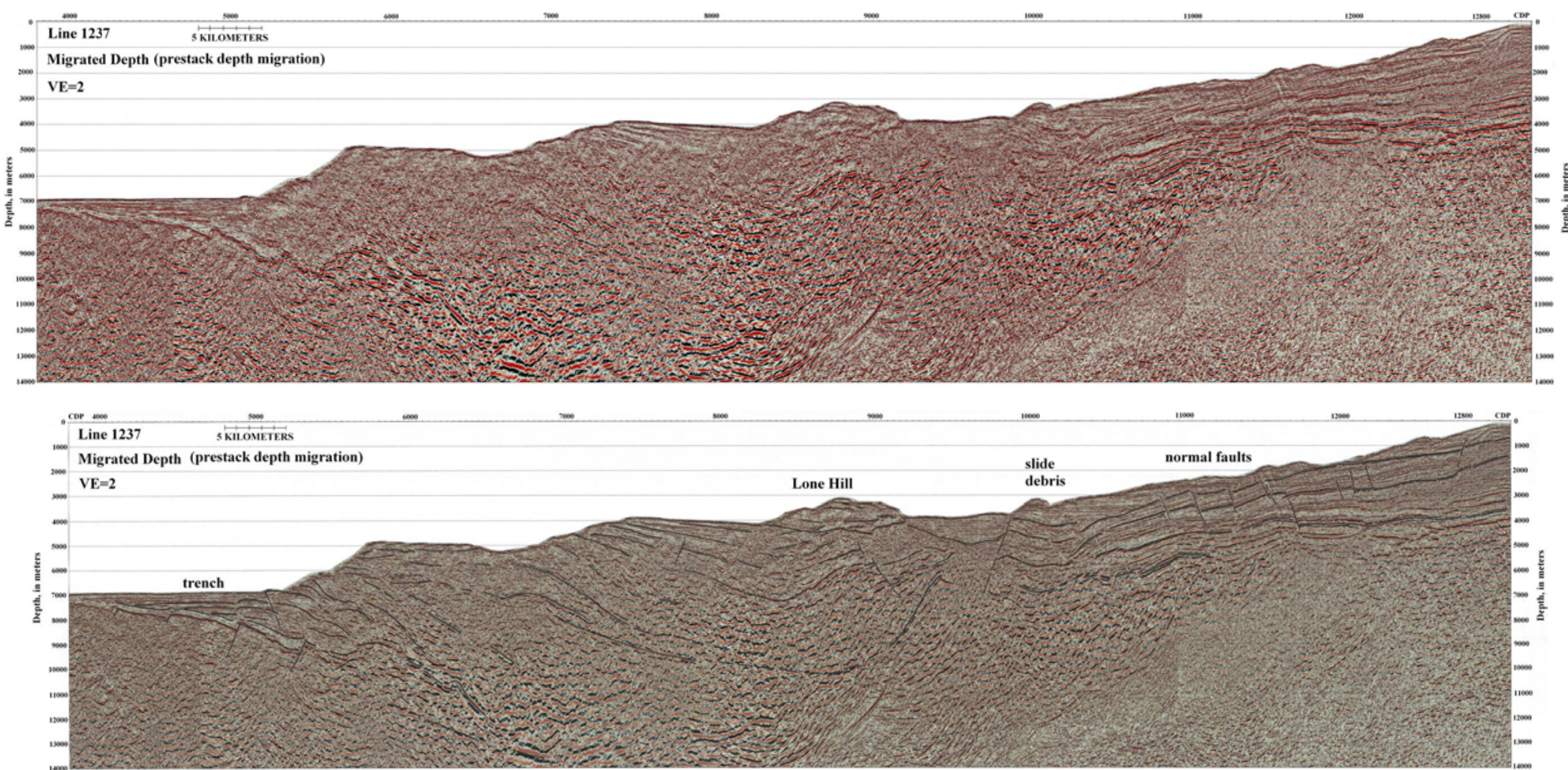

Left click on the two leftmost links below to display the above images in high resolution. Right click on any of the three links below to download the images or the processed seismic data-file in SEG-Y format.

\begin{tabular}{|c|c|c|}
\hline $\begin{array}{c}\text { Uninterpreted Image } \\
\text { (jpeg format roughly 8 MB) }\end{array}$ & $\begin{array}{c}\text { Interpreted Image } \\
\text { (jpeg format roughly 8 MB) }\end{array}$ & $\begin{array}{c}\text { Download SEG-Y file } \\
\text { (SEG-Y format roughly 150 MB) }\end{array}$ \\
\hline
\end{tabular}

LINE 1237 The published line drawing of this seismic image was made from a previous display (von Huene and others, 2012). At the trench axis, the frontal prism was deformed by a subducting seamount (fig. 2). The mid-slope terrace is underlain by the Cenozoic shelf and slope strata in a broad synform that is broken by many faults with vertical displacement (roughly 100 meters [m] or less). On the terrace is the 800-m-high Lone Hill of stratified material. A high-amplitude basal reflection beneath the hill may indicate trapped fluids. Its irregular character reflects the diagonal crosscutting of structure by the seismic line. 
Table 2. Seismic images of the five seismic lines used in this report. Top: uninterpreted; Bottom: interpreted with simple form lines. Two links below each interpreted image provide the means to view the images in high resolution or to download the high-resolution file in jpeg-format. A third link allows the reader to download the processed seismic data in SEG-Y format. VE, Vertical Exaggeration.-Continued
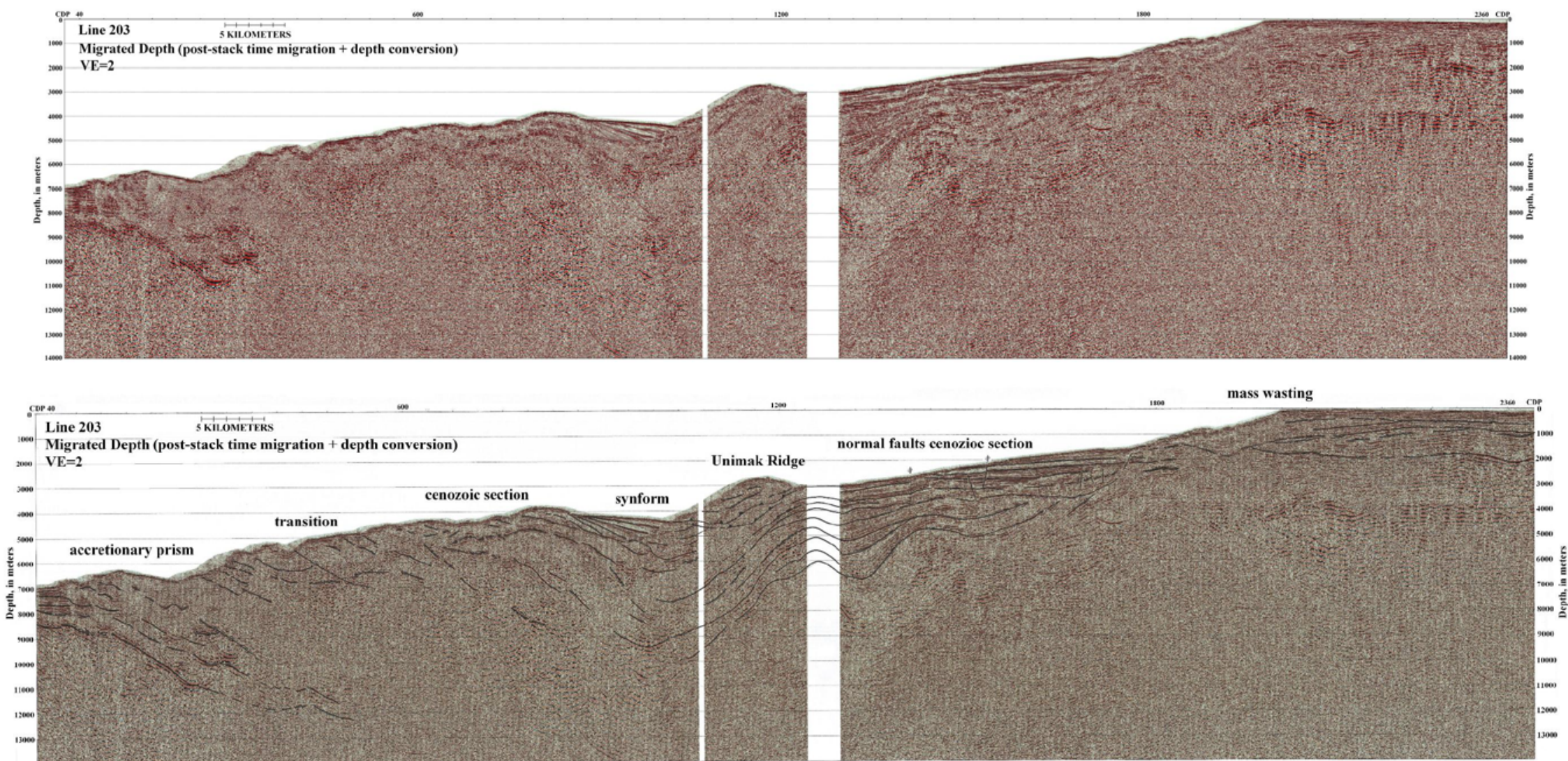

Left click on the two leftmost links below to display the above images in high resolution. Right click on any of the three links below to download the images or the processed seismic data-file in SEG-Y format.

\begin{tabular}{|c|c|c|}
\hline $\begin{array}{c}\text { Uninterpreted Image } \\
\text { (jpeg format roughly 4 MB) }\end{array}$ & $\begin{array}{c}\text { Interpreted Image } \\
\text { (jpeg format roughly 4 MB) }\end{array}$ & $\begin{array}{c}\text { Download SEG-Y file } \\
\text { (SEG-Y format roughly 63 MB) }\end{array}$ \\
\hline
\end{tabular}

LINE 203 An upper-slope unconformity between relatively high- and low-frequency reflections is the inferred contact between the upper and middle series strata of Bruns and others (1987). The underlying discontinuous low-frequency reflections are lower series. At the shelf edge, slope failure left a rough morphology of scarps and slide debris. Upper-slope normal faults are observed in seismic and bathymetric images (fig. 2). The terrace is underlain by two broad folds. The almost 2-kilometer (km)-high Unimak Ridge sits on the seaward one and its base is defined by discordant, weakly reflective strata seen best at high magnification. 
Table 2. Seismic images of the five seismic lines used in this report. Top: uninterpreted; Bottom: interpreted with simple form lines. Two links below each interpreted image provide the means to view the images in high resolution or to download the high resolution file in jpeg-format. A third link allows the reader to download the processed seismic data in SEG-Y format. VE, Vertical Exaggeration.-Continued
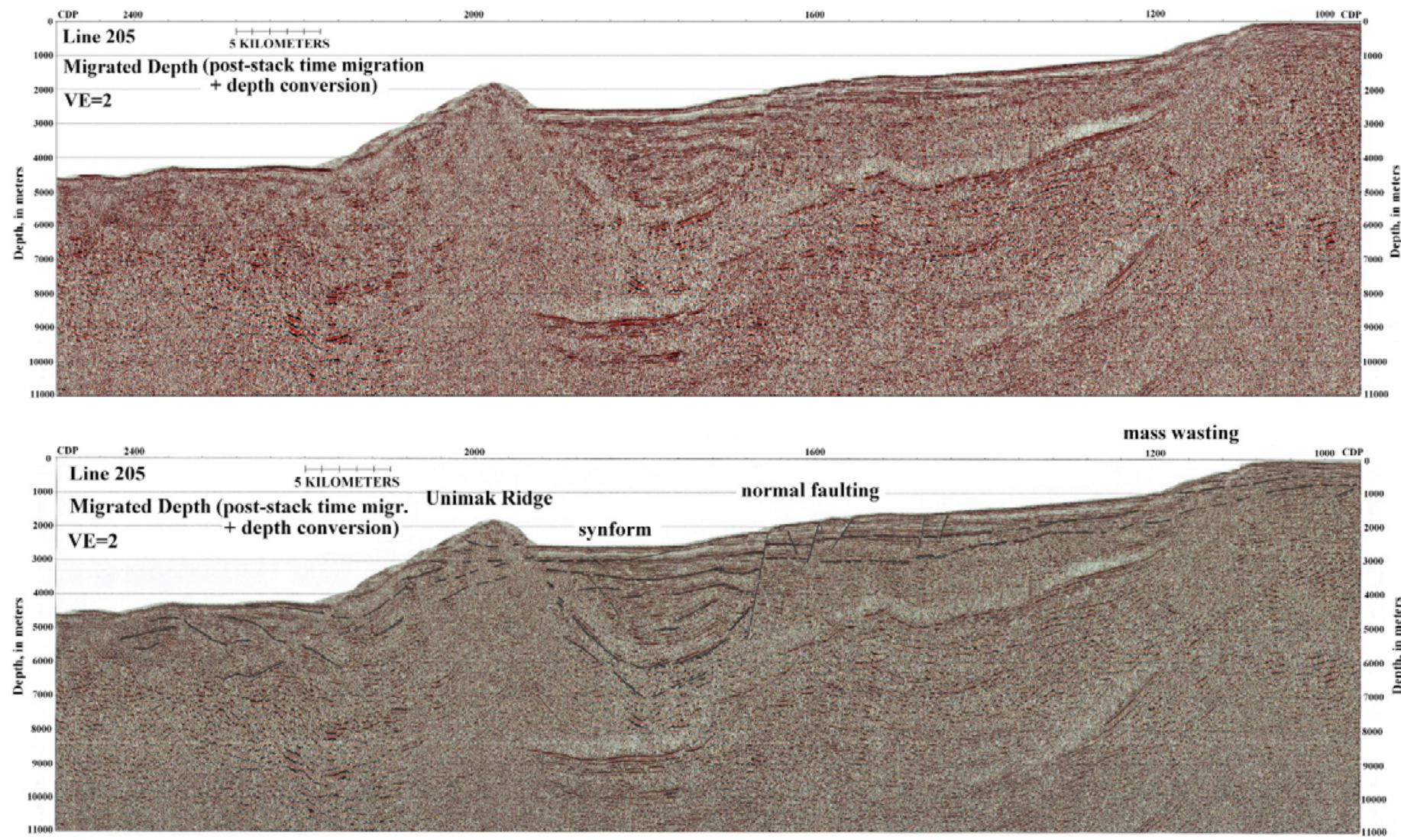

Left click on the two leftmost links below to display the above images in high resolution. Right click on any of the three links below to download the images or the processed seismic data-file in SEG-Y format.

\begin{tabular}{|c|c|c|}
\hline $\begin{array}{c}\text { Uninterpreted Image } \\
\text { (jpeg format roughly 4 MB) }\end{array}$ & $\begin{array}{c}\text { Interpreted Image } \\
\text { (jpeg format roughly 4 MB) }\end{array}$ & $\begin{array}{c}\text { Download SEG-Y file } \\
\text { (SEG-Y format roughly 63 MB) }\end{array}$ \\
\hline
\end{tabular}

LINE 205 A time section of Line 205 is the principal illustration of Unimak Ridge in Bruns and others (1987). Its non-stratified internal character is replaced by weak-stratal reflectivity in the reprocessed seismic data. The basal contact is recognized from stratal discordance of weak reflections. A 4-km-deep synform on the upslope side of the ridge is followed by a weakly reflective antiform beneath the ridge. Discontinuous and poor-quality data seaward of the ridge were not processed. 
Table 2. Seismic images of the five seismic lines used in this report. Top: uninterpreted; Bottom: interpreted with simple form lines. Two links below each interpreted image provide the means to view the images in high resolution or to download the high resolution file in jpeg-format. A third link allows the reader to download the processed seismic data in SEG-Y format. VE, Vertical Exaggeration.-Continued
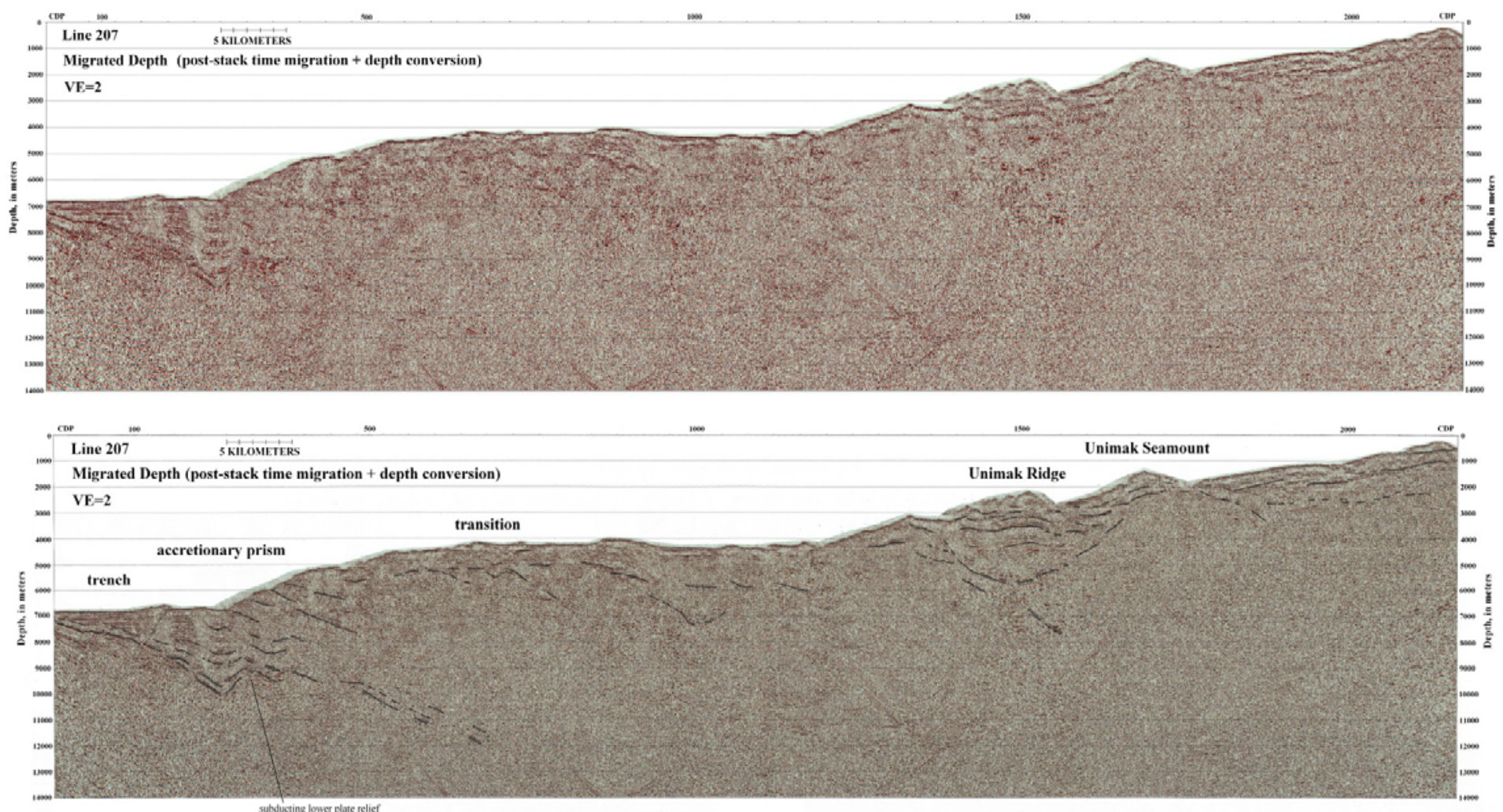

Left click on the two leftmost links below to display the above images in high resolution. Right click on any of the three links below to download the images or the processed seismic data-file in SEG-Y format.

\begin{tabular}{|c|c|c|}
\hline $\begin{array}{c}\text { Uninterpreted Image } \\
\text { (jpeg format roughly } 4 \mathrm{MB} \text { ) }\end{array}$ & $\begin{array}{c}\text { Interpreted Image } \\
\text { (jpeg format roughly } 4 \mathrm{MB} \text { ) }\end{array}$ & $\begin{array}{c}\text { Download SEG-Y file } \\
\text { (SEG-Y format roughly } 63 \mathrm{MB} \text { ) }\end{array}$ \\
\hline
\end{tabular}

LINE 207 The poor stratal image quality may be caused by basement of Sanak Ridge. On the upper slope, extensional faults are poorly imaged because they strike at an angle to the plane of section. On the terrace, the line passes between the offset ends of the ridge and the seamount segments complicating its image with reflections from out-of-theplane of section. Although the Cenozoic sediment section is broken and deformed locally, its seismic stratigraphy is similar to the upper slope sequence. 
Table 2. Seismic images of the five seismic lines used in this report. Top: uninterpreted; Bottom: interpreted with simple form lines. Two links below each interpreted image provide the means to view the images in high resolution or to download the high resolution file in jpeg-format. A third link allows the reader to download the processed seismic data in SEG-Y format. VE, Vertical Exaggeration.-Continued
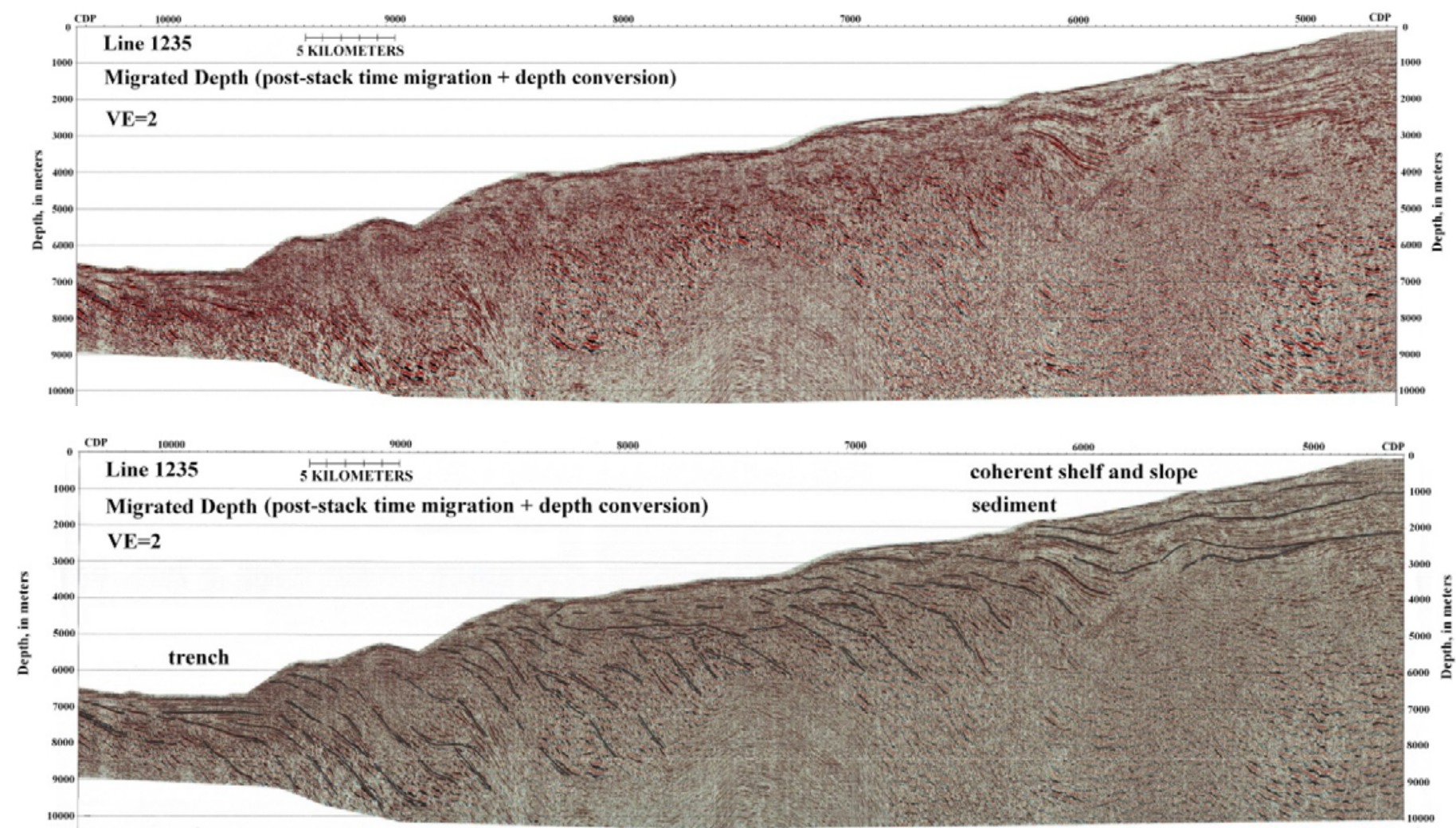

Left click on the two leftmost links below to display the above images in high resolution. Right click on any of the three links below to download the images or the processed seismic data-file in SEG-Y format.

\begin{tabular}{|c|c|c|}
\hline $\begin{array}{l}\text { Uninterpreted Image } \\
\text { (jpeg format roughly } 4 \mathrm{MB} \text { ) }\end{array}$ & $\begin{array}{c}\text { Interpreted Image } \\
\text { (jpeg format roughly } 4 \mathrm{MB} \text { ) }\end{array}$ & $\begin{array}{c}\text { Download SEG-Y file } \\
\text { (SEG-Y format roughly } 63 \mathrm{MB} \text { ) }\end{array}$ \\
\hline
\end{tabular}

LINE 1235 This line is to the east of Unimak Seamount and at the western end of the Alaska margin transition to the Aleutian margin. Its structure differs from the adjacent Unimak area. The seismic image deeper than 4 or $5 \mathrm{~km}$ reveals few reflectors, and we interpret it as igneous rock intruded into the Cretaceous metamorphic unit that crops out on the Shumagin Islands. Shelf-sediment sequences are clearly imaged to $3 \mathrm{~km}$ water depth and obscured beyond. 


\section{Discussion}

\section{Origin of Mid-Slope Ridges}

One of the primary objectives of this study is to clarify possible sources for both the nearand the far-field components of the 1946 tsunami. Previous investigations concluded without finding a clear indication of any reasonably large 1946 landslide features, but did not exclude that slope failure or splay faulting were somehow involved. Imaging of Lone Hill as a stratified mass (von Huene and others, 2012) initiated consideration of the entire Unimak Ridge as a potential slope-failure mass. The origin of Unimak Ridge morphology from slope failure is a possibility supported by the extensive normal faults upslope (figs. 2 and 3). This possibility of slope failure in the 1946 aftershock area is advanced by better resolved new features in the reprocessed USGS and RV Ewing seismic data. Line 1237 clearly images nearly horizontal strata in a coherent slide mass resting on stratified material.

Line 203 crosses the western end of Unimak Ridge. Seaward-dipping strata are imaged to $10 \mathrm{~km}$ depth in the reflection images. A synform of strata begins on the seaward side of the ridge and extends beneath the mid-slope terrace. Above the synform, a fan of ponded sediment seaward of the ridge indicates tectonic rotation. Despite a gap in data, the structure of the ridge indicates counterclockwise rotation of a roughly $12-\mathrm{km}$-wide block.

Line 205 was illustrated in Bruns and others (1987), to show the structure of Unimak Ridge. This image shows only the profile of the ridge and contained no coherent internal structure. Steeply dipping coherent stratification was resolved in the reprocessed image and the reflectors that indicate structure within the ridge are probably weak because the steep flanks of the ridge scatter the reflected energy at the seafloor interface. A deep-stratified synform of Cenozoic sediment is imaged on the upslope side of the ridge. Ponded sediment $500 \mathrm{~m}$ thick fills a 20-km wide basin farther upslope indicating a time of ridge formation earlier than that of Lone Hill. The structural relation between the ridge and the synform, whether growth faulting or simple onlap, is unclear and open to various interpretations.

The adjacent Line 207 extends across the juncture of the Unimak Ridge and Unimak Seamount segment. Despite much out-of-plane reflectivity, the stratified character of the Unimak Ridge and Unimak Seamount segment is imaged. The deeper margin framework below $3 \mathrm{~km}$ of the Unimak Seamount segment is obscured, whereas the segment beneath Unimak Ridge shows a broad synform. The underlying basement structure probably strikes parallel to seafloor morphology that curves from the Beringian to Alaskan margin trend. This oblique trend to the plane of the seismic section could produce the decrease in reflective strength.

We have no seismic information across Unimak Seamount, but it is not far from the probable intrusive masses that crop out on Sanak Island ridge and the Shumagin Islands. Seamount lithology was inferred from two dredge hauls containing Eocene-aged basalt. The origin proposed by Bruns and others (1987), suggesting that the ridges are tectonically rotated blocks, is an explanation supported by the seismic-reflection data. Rotation seaward of the ridges is shown by sediment fans in three of the seismic lines.

The southwest flank of the Shumagin Islands basement mass was probably imaged in seismic Line 1235. Shumagin Islands expose the top of a broad basement ridge that is separated from the Sanak Island Basement Ridge by the intervening 7-km-deep Unimak Basin (Bruns and others, 1987). Aftershocks during the first 19 days following the 1946 earthquake diminish significantly at the Sanak Basin and Shumagin basement high. The upper slope contains the seaward end of the Sanak Basin. The middle- and lower-slope image is not as clear as those up slope, nor is the structure well defined. 
Prior to early Eocene development of the Aleutian Arc, the Alaska Peninsula was underthrust by the Kula-Resurrection spreading ridge (Haeussler and others, 2003). Subduction of the ridge exposed the upper plate to a slab window that left near-trench plutons as it migrated from west to east beneath Alaska. Igneous plutons in the upper plate are exposed on both the Sanak and the Shumagin Islands. Perhaps Unimak Seamount exposes plutonic rock that forms a buried basement along the mid-slope elevated feature.

\section{A Near-Field Tsunami Source}

The newly processed reflection images presented here are interpreted to be consistent with the near-field and far-field sources that have been suggested to explain the 1946 tsunami (Okal and Hebert, 2007). Local tsunamis are commonly produced by slope failure, whereas farfield tsunamis as large as that of 1946 require extensive displacement of the seafloor. A nearfield tsunami source is indicated by the local nature of high runup along the Alaskan Peninsula. The 15-20 m high runup extended northeast of Scotch Cap, as far as Sanak Island (135 km from Scotch Cap); only a modest wave was recorded at Dutch Harbor, $85 \mathrm{~km}$ southwest of Scotch Cap (Okal and others, 2003). A possible near-field tsunami source is Lone Hill (fig. 3) and the adjacent debris field crossed by Line 1237 through Unimak Pass (fig. 2). Slide masses consisting of multiple kilometer-wide blocks, rather than a downslope flow of dissociated material aggregates, are recognizable in multibeam bathymetry. Coherent blocks leave traces that differ from the classical spoon-shaped scars and rough debris fields. From side-scan (GLORIA) imagery, Lone Hill was at one time interpreted as the downslope end of a landslide across the upper slope (Fryer and others, 2004). However, the slide path was absent in the RV Ravelle multibeam survey, and Lone Hill was considered at that time to be the end of the "igneous Unimak Ridge" (Rathburn and others, 2009). Subsequently, strata both in and underlying Lone Hill were imaged in Line 1237 which contradicted the interpretation of an igneous origin (von Huene and others, 2012).

Lone Hill measures $11 \mathrm{~km}$ along Line 1237, it is up to $800 \mathrm{~m}$ high, and at least $1 \mathrm{~km}$ thick (fig. 4). In map view, Line 1237 crosses linear morphology trending at a $30^{\circ}$ angle, which introduces reflectivity from out-of-the-plane of section image. A high-amplitude reflection beneath the landward side forms the contact between Lone Hill and its substructures (table 2). Strong reflectivity can indicate undrained fluids which could result from rapid loading by a massive slide block. The allochthonous origin of Lone Hill is clear from stratification. A 0.5-1.0 $\mathrm{km}$ high stratified mass sitting on a deformed, but coherent, sediment section is problematic to form otherwise. The stratification beneath and within this structure, resolved in the seismic images, is interpreted as consistent with that of wide-angle seismic information, which indicates that no high velocity rock body projects into the sediment section (Lizarralde and others, 2002).

Across the upper slope, the Cenozoic section has been tilted toward the trench and extended along normal faults that are incipient landslide headwalls. The origin of a $500 \mathrm{~m}$ high scarp upslope from Lone Hill and at the base of the upper slope was an extensional fault imaged in Line 1237 (table 2). A trail of debris extends downslope from the scarp to Lone Hill and may indicate a path of migration (figs. 3, 4). Restoring Lone Hill on a path along the debris trail to near the escarpment joins a ridge and a valley showing a possible source area about $10 \mathrm{~km}$ away. At the base of the scarp is a lobe of slide debris about $20 \mathrm{~km}$ wide along strike (fig. 4). This lobe may be from a slide block that disintegrated during sliding or from multiple small slides. The lobe and Lone Hill distance from Scotch Cap is theoretically within the distance calculated from the reported time for the tsunami to reach the lighthouse (Fryer and others, 2004). A landslide origin for Lone Hill and the slide-debris lobe explains their origins and their potential relation to the 1946 near-field event and might be further resolved with high resolution multibeam bathymetry, seismic-reflection data, and conventional sampling. 
The USGS seismic images resolve strata less clearly within Unimak Ridge than the RV Ewing data resolved them within Lone Hill, as would be expected from a smaller acquisition system. The Ridge's steep slopes also deflect seismic signals. In each of the older lines, broad folds in the underlying stratified rock are associated with Unimak Ridge. Multibeam bathymetry reveals segmentation of the Unimak mid-slope elevated structure. Features associated with Lone Hill indicate a relatively recent origin, whereas Unimak Ridge appears to have formed at an earlier time because sediment has ponded behind it. Therefore, the most likely candidates for the 1946 near-field tsunami source are Lone Hill and (or) the adjacent slide-debris field (fig. 2). Their upslope detachment scarp has a steep and minimally eroded morphology indicating a recent origin. The absence of a fresh source detachment feature for Unimak Ridge is further evidence that it has not recently slid from upslope.

\section{Far-Field Tsunami Source}

In theory, far-field tsunamis are produced most effectively in deep water because the displaced column of water is greatest. The 1946 tsunamigenic-earthquake epicenter is located in the lower slope area. Tsunamigenic earthquakes along the Alaska margin have occurred in segments bounded by upper- and lower-plate features (von Huene and others, 2012). The 1946 aftershock seismicity appears to define a rupture segment that may be confined laterally by upper-plate features. A northeast limit of aftershocks occurs at the proposed igneous basement adjacent to the Shumagin Islands interpreted in Line 1235 (fig. 1; table 2). The southwest aftershock area limit is near Unimak Pass where geophysical data are limited. A USGS line with many gaps, L12-82-201 (Bruns and others, 1987), may image igneous-arc comprising acoustic basement. Above the possible igneous basement is an upper slope embayment onto the shelf (fig. 1). To discern whether a geologic feature impedes earthquake rupture near to Unimak Pass is equivocal. There was some overlap between the aftershock areas of the 1946 event and those of the adjacent 1957 Fox Islands event to the west, however, the main rupture areas, where most moment was released, were separated. Consequently, the 1946 aftershock distribution could indicate an earthquake rupture segment where repeated events could occur.

Based on our interpretations of the improved seismic images, the 1946 earthquake epicenter occurred beneath the seaward end of the continental framework, rather than the accretionary prism. Some investigators consider the 1946 epicenteral area an accretionary prism (compare with Lewis and others, 1988; Tanioka and Seno, 2001). It seems questionable that an Mw 8.6 earthquake would be generated beneath young accreting sediment, because this sediment is commonly weak. Most of the Unimak margin prism probably accreted during the past 3 million years when trench sediment volumes increased because of glaciation in the Gulf of Alaska (von Huene and others, 2012). The accreted prism seismic velocities are roughly 2-3 $\mathrm{km} / \mathrm{s}$ compared to $3.0-6.5 \mathrm{~km} / \mathrm{s}$ in continental framework rocks (Bruns and others, 1987; Lizarralde and others, 2002). Low velocities and recent accretion are typical of sediments that have low shear strength and can store only a limited amount of elastic strain. In the Unimak segment, the width of the accretionary prism in seismic images is between 15 and $27 \mathrm{~km}$. The 1946 epicenter (Lopéz and Okal, 2006) is about $35 \mathrm{~km}$ from the trench axis although the location uncertainty may be noteworthy. At the plotted location, the epicenter was about $15 \mathrm{~km}$ inboard of the accreting prism interpreted from bathymetry. Here the upper plate is 5 to $8 \mathrm{~km}$ thick in both the reflection seismic images and in wide-angle data (Lizarralde and others, 2002).

Consolidated upper-plate rock that can store significant elastic strain is a more likely location for the 1946 earthquake epicenter than a less consolidated accreting prism. However, the epicenter location is open to reinterpretation in the future if a more refined velocity model than that of Lopéz and Okal (2006) is found to differ significantly. 
Since data in the Unimak segment are relatively sparse, a comparison to information from the extensively documented Tohoku margin can be used to imply possible mechanics. Seismic velocities of $1.7-2.8 \mathrm{~km} / \mathrm{s}$ in the frontal prism and $4.2-6.2 \mathrm{~km} / \mathrm{s}$ in the margin framework at the 2011 Tohoku rupture (Tsuru and others, 2002; Chester and others, 2012; Lin and others, 2013) are essentially the same as those observed along the Unimak margin. During the 2011 Tohoku earthquake, rupture propagated about $60 \mathrm{~km}$ from the epicenter up the subduction zone to the trench axis. A similar seaward propagation of slip from the 1946 epicenter into the frontal prism is consistent with current aftershock distribution, with contractile tectonic structures and with slope instability (fig. 2). The lower slope "jumbled" seafloor morphology of both margins is characteristic of many frontal prisms, especially in the presence of subducting lower-plate relief like that imaged in lines 1237 and 207 (fig. 1). To summarize, the 1946 epicenter location is in an environment similar to that of Tohoku. Significant slip and seafloor deformation in deep water is consistent with the large 1946 far-field tsunami and with current ideas about far-field tsunami generation. The quantified size of the Tohoku tsunami (Ide and others, 2011) and that of the 1946 tsunami (Abe, 1979) are essentially equivalent. However, the vastly different nearby coastal populations were as dissimilar as the devastation. The less densely populated California coast in 1946 was severely damaged (Lander and others, 1993) despite its position at the outer edge of intense wave-height focus (Fryer, oral commun., 2010).

Considering the structural similarities between the Unimak and Tohoku margins (Ryan and others, 2012), the Tohoku tsunami dynamics could be a model for those of the 1946 Unimak tsunami. A broader implication of both earthquakes is the steepening landward slopes as eroding margins subside. This makes them potential areas for massive slope failure. The slides are large enough to be near-field tsunami sources concurrent with a large earthquake rupture that displaces the deep seafloor and generates far-field tsunamis. The 1992 Nicaragua and 1960 Chile tsunamis were sourced along margins where kilometer-wide landslide scars are numerous. During coseismic events, coupling along slide interfaces is reduced by dynamic rather than static friction, thereby promoting catastrophic landslides in unstable seismogenic environments.

\section{Conclusions}

The 1946 Unimak Island earthquake epicenter was located in a shallow part of the Alaska subduction zone, perhaps $35 \mathrm{~km}$ from the Alaska/Aleutian trench axis, where the 5-8 km thick upper plate is composed of acoustic basement. Basement rock has "margin framework" rock characteristics and seismic velocities of $4-6 \mathrm{~km} / \mathrm{s}$ that are typical of the well-consolidated metamorphic and intrusive rocks exposed in the adjacent Shumagin and Sanak Islands (Bruns and others, 1987; Lizarralde and others, 2002). Such rock can store sufficient strain to generate an Mw 8.6 earthquake such as the one that occurred in 1946.

High runup from a tsunami was observed along a limited area of the Alaska Peninsula coast. This limited extent is common to local tsunamis caused by slope failure. The distance of a landslide source from Scotch Cap was constrained by the time between when earthquake shaking was felt and inundation occurred. No large, classical spoon-shaped slide scars occur on the upper slope within that distance. However, seismic reflection images show an isolated hill (Lone Hill) of stratified rock up to $15 \mathrm{~km}$ wide that has slid on top of a Cenozoic sediment section. This structural relation is most easily explained by catastrophic sliding of a detached block onto the mid-slope terrace. Trapped fluid in underlying strata may have been loaded suddenly and depressed as the block slid on to the mid-slope sediment section. A 500-m-high scarp upslope from the block is the likely source area. Between the hill and the scarp is a large slide-debris field indicating that the edges of the block may have disintegrated. Recent bathymetry (Lim and others, 2011) shows separation of the hill from the mid-slope Unimak Ridge; the hill is therefore 
not an extension of Unimak Ridge. Structure of the Unimak Ridge indicates an origin by rotation of a roughly 12- km-wide block at an earlier time than formation of the isolated hill. Dating samples that relate the hill to the 1946 earthquake is possible on future research expeditions and could improve understanding of the local tsunami.

The size of the 1946 Unimak Island/Scotch Cap far-field tsunami is comparable to that of the 2011 Tohoku tsunami. Their tectonic structures are also very similar. As in the 2011 Tohoku event, earthquake rupture may have propagated from the mid-slope up the subduction zone to deform the less consolidated accretionary prism seafloor. The epicenter's deep water location caused seafloor displacement beneath a multiple-kilometer-high water column which would theoretically generate the large far-field tsunami. The generation mechanics of the 1946 tsunami have many similarities with the 2011 Tohoku tsunami, and further study can help improve understanding of tsunami sources at Alaska's erosional margins.

\section{Acknowledgments}

We thank Peter Haeussler who funded travel for Roland von Huene and Mike Tryon for the bathymetric data in figure 2. Gerard Fryer and Dave Scholl are thanked for helpful discussions as well as the U.S. Geological Survey (USGS) Tsunami Source Working Group. The RV Ewing seismic data were acquired by Steve Holbrook and Nathan Bangs who kindly agreed to let us process and publish them. We thank Ginger Barth and Dave Scholl of the USGS for their technical reviews of the manuscript.

\section{References Cited}

Abe, K., 1979, Size of great earthquakes of 1837-1974 inferred from tsunami data: Journal of Geophysical Research, v. 84, p. 1,561-1,568, doi:10.1029/JB084iB04p01561.

Barry, K.M., Cavers, D.A., and Kneale, C.W., 1975, Recommended standards for digital tape formats, in Digital Tape Standards: Society of Exploration Geophysicists, reprinted from Geophysics, v. 40, p. 344-352.

Bruns, T.R., Von Huene, R., Culotta, R.C., Lewis, S.D., and Ladd, J.W., 1987, Geology and petroleum potential of the Shumagin Margin, Alaska, chap. 8 of Scholl, D., Grantz, A. and Vedder, J., eds., Geology and potential of the continental margin of western North America and adjacent basis: Circumpacific Council for Energy and Mineral Resources, Houston, Tex., p. $157-189$.

Chester, F.M., Mori, J.J., Toczko, N., and Eguchi, S.N., the Expedition 343/343T Scientists, Japan Trench Fast Drilling Project (JFAST), 2012, IODP Preliminary Report 343/343T: Japan Trench Fast Drilling Project, 10.2204/iodp.pr.343343T.2012

Flueh, Ernst R. and von Huene, Roland, 1994, FS Sonne fahrtbericht SO 96 Kodiak Seis: GEOMAR Research Center for Marine geosciences, Christian Albrechts University in Kiel; www.geomar.de, 209 p.

Fryer, G.J., and Tryon, M.D., 2005, Great earthquakes, gigantic landslides, and the continuing enigma of the April Fool's tsunami of 1946: Eos Transactions AGU86, v. 52, T11A-0355.

Fryer, G.J., Watts, P., and Pratson, L.F., 2004. Source of the great tsunami of 1 April 1946-A landslide in the upper Aleutian forearc: Marine Geology v. 204, p, 201-218.

Haeussler, P.J., Bradley, D.W., Wells, R.E., and Miller, M.I., 2003, Life and death of the Resurrection plate, evidence for its existence and subduction in the northeastern Pacific in Paleocene-Eocene time: Geological Society of America Bulletin, v. 115, no. 7, p. 867-880, doi: 10.1130/0016-7606(2003)115<0867:LADOTR>2.0.CO;2. 
Ide, S., Baltay, A., and Beroza, G C., 2011, Shallow dynamic overshoot and energetic deep rupture in the $2011 \mathrm{Mw} 9.0$ Tohoku-Oki earthquake: Science, v. 332, p. 1,426-1,429, doi: $10.1126 /$ science. 1207020 .

Johnson, J.M., and Satake, K., 1997, Estimation of seismic moment and slip distribution of the April 1, 1946, Aleutian tsunami earthquake: Journal of Geophysical Research, v. 102, p. $11,765-11,774$.

Kanamori, H., 1972, Mechanism of tsunami earthquakes: Physics of the Earth and Planetary Interiors, v. 6, p. 346-359.

Lander, J.F., Lockridge, P.A., and Kozuch, M.A., 1993, Tsunamis affecting the U.S. West Coast, 1806-1992: National Oceanic and Atmospheric Administration, NGDC key to geophysical records documentation, no. 29.

Lewis, S.D., Ladd, J.W., and Bruns, T.R., 1988, Structural development of an accretionary prism by thrust and strike-slip faulting-Shumagin region, Aleutian Trench: Geological Society of America Bulletin, v. 100, p. 767-782.

Lim, E., Eakins, B.W., and Wigley, R., 2011, Coastal relief model of southern AlaskaProcedures, data sources and analysis: National Oceanic and Atmospheric Administration Technical Memorandum NESDIS NGDC-43, 22 p.

Lin, Weiren, Conin, Marianne, Moore, J.C., Chester, F.M., Nakamura, Yasuyuki, Mori, J.J., Anderson, Louise, Brodsky, E.E., and Eguchi, Nobuhisa, Expedition 343 Scientists, 2013, Stress state in the largest displacement area of the 2011 Tohoku-Oki Earthquake: Science, v. 339, no. 6,120, p. 687-690, DOI: 10.1126/science.1229379.

Lopéz, A., and Okal, E.A., 2006, A seismological reassessment of the source of the 1946 Aleutian ‘tsunami' earthquake: Geophysical Journal International, v. 165, p. 835-849.

Lizarralde, D., Holbrook, S.W., McGeary, S., Bangs, N., and Diebold, J., 2002, Crustal construction of a volcanic arc, wide-angle seismic results from the western Alaska Peninsula: Journal of Geophysical Research, v. 107, no. B8, p. 2,164, 10.1029/2001JB000230

Okal, Emile A., and Hébert, Héléne, 2007, Far-field simulation of the 1946 Aleutian tsunami, Geophysical Journal International, v. 169, p. 1,229-1,238, doi: 10.1111/j.1365246X.2007.03375.X

Okal, E.A., Plafker, G., Synolakis, C.E., and Borrero, J.C., 2003, Near-field survey of the 1946 Aleutian tsunami on Unimak and Sanak Islands: Bulletin of the Seismological Society of America, v. 93, p. 1,226-1,234.

Okal, Emile A., Synolakis, Costas E., Fryer, Gerard J., Heinrich, Philippe, Borrero, José C., Ruscher, Christophe, Arcas, Diego, Guille, Gérard and Rousseau, Daniel, 2002, A field survey of the 1946 Aleutian tsunami in the far field: Seismological Research Letters, v. 73, p. 490-503. Rathburn, A.E., Levin, L.A., Tryon, M., Gieskes, J.M., Martin, J.B., Perez, M.E., Fodrie, F.J., Neira, C., Fryer, G.J., Mendoza, G., McMillan, P.A., Kluesner, J., Adamic, J., Zeibis, W., 2009, Geological and biological heterogeneity of the Aleutian margin (1965-4822 m): Progress in Oceanography, v. 80, p. 22-50.

Ryan, H., von Huene, R., Scholl, D., and Kirby, S., 2012. Tsunami hazards to U.S. Coasts from giant earthquakes in Alaska: Eos, Transactions of the American Geophysical Union, v. 93, p. 185-186.

Tanioka, Y., and Seno, T.,2001, Detailed analysis of tsunami wave forms generated by the 1946 Aleutian tsunami earthquake: Natural Hazards and Earth Systems Sciences, v. 1, p. 171-175.

Tsuru, Tetsuro, Park, Jin-Oh, Miura, Seiichi, Kodaira, Shuichi, Kido, Yukari, and Hayashi, Tsutomu, 2002, Along-arc structural variation of the plate boundary at the Japan Trench margin-Implication of interplate coupling: Journal of Geophysical Research, v. 107, no. B12, p. 2,357, doi:10.1029/2001JB001664, 2002 
von Huene, R., Miller, J., and Weinrebe, W., 2012, Subducting plate geology in three great earthquake ruptures on the western Alaska margin, Kodiak to Unimak [online]: Geosphere, v. 8 , no. 3, 17 p., doi:10.1130/ GES00715.

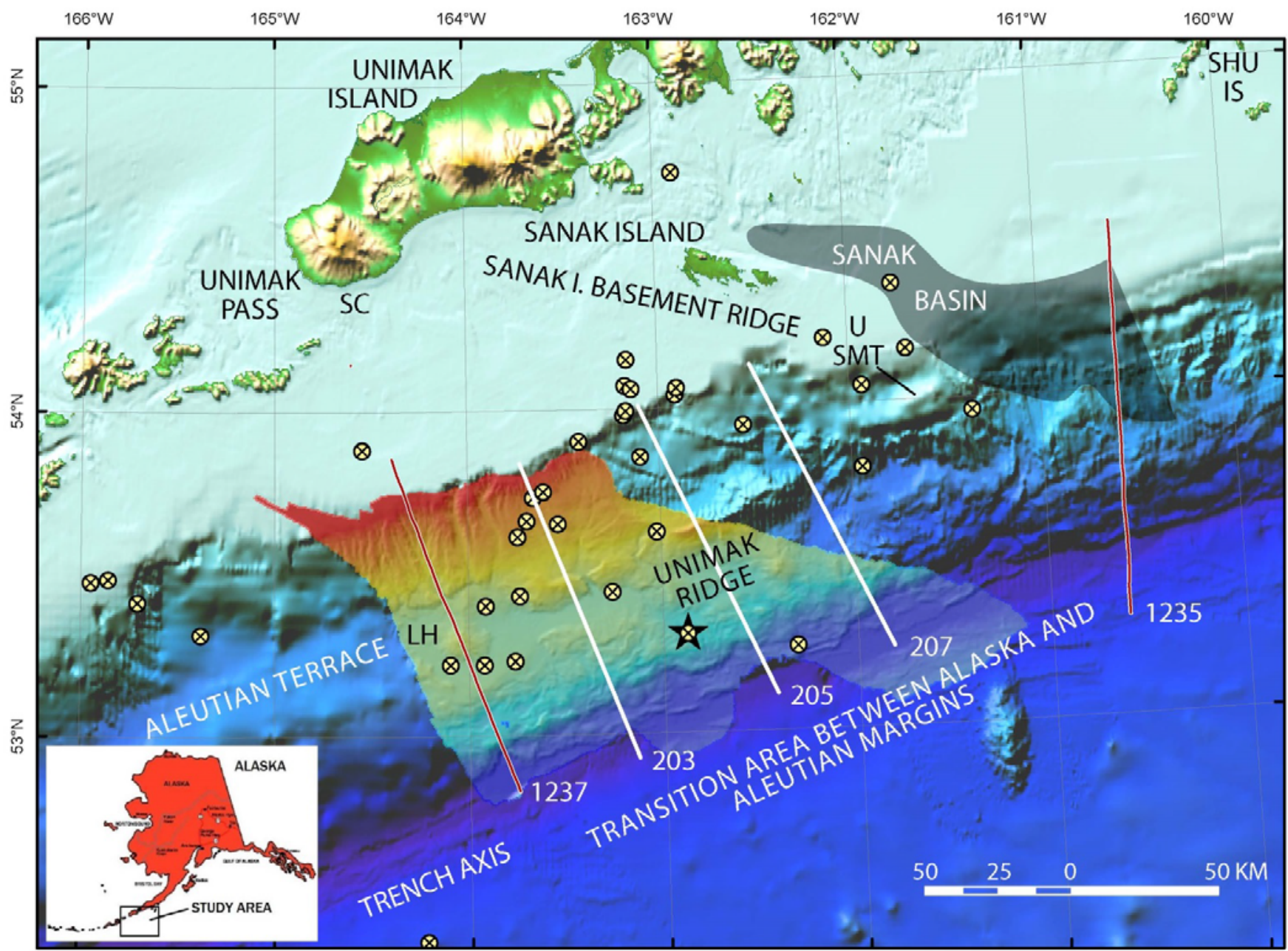

Figure 1. Unimak margin bathymetric compilation (Lim and others, 2011) from Unimak Pass to the outer Shumagin Islands. Numbered lines indicate seismic-reflection transects, the star is the 1946 earthquake epicenter, and the small circles are aftershock locations (Lopéz and Okal, 2006). The location of figure 2 is shown in the superimposed colored area. Color scheme: Red is shallow beginning at roughly 1,000 meters and dark blue is deeper than 6,000 meters. [SC, Scotch Cap; SHU IS, Shumagin Island group; LH, Lone Hill; U SMT, Unimak Seamount] 


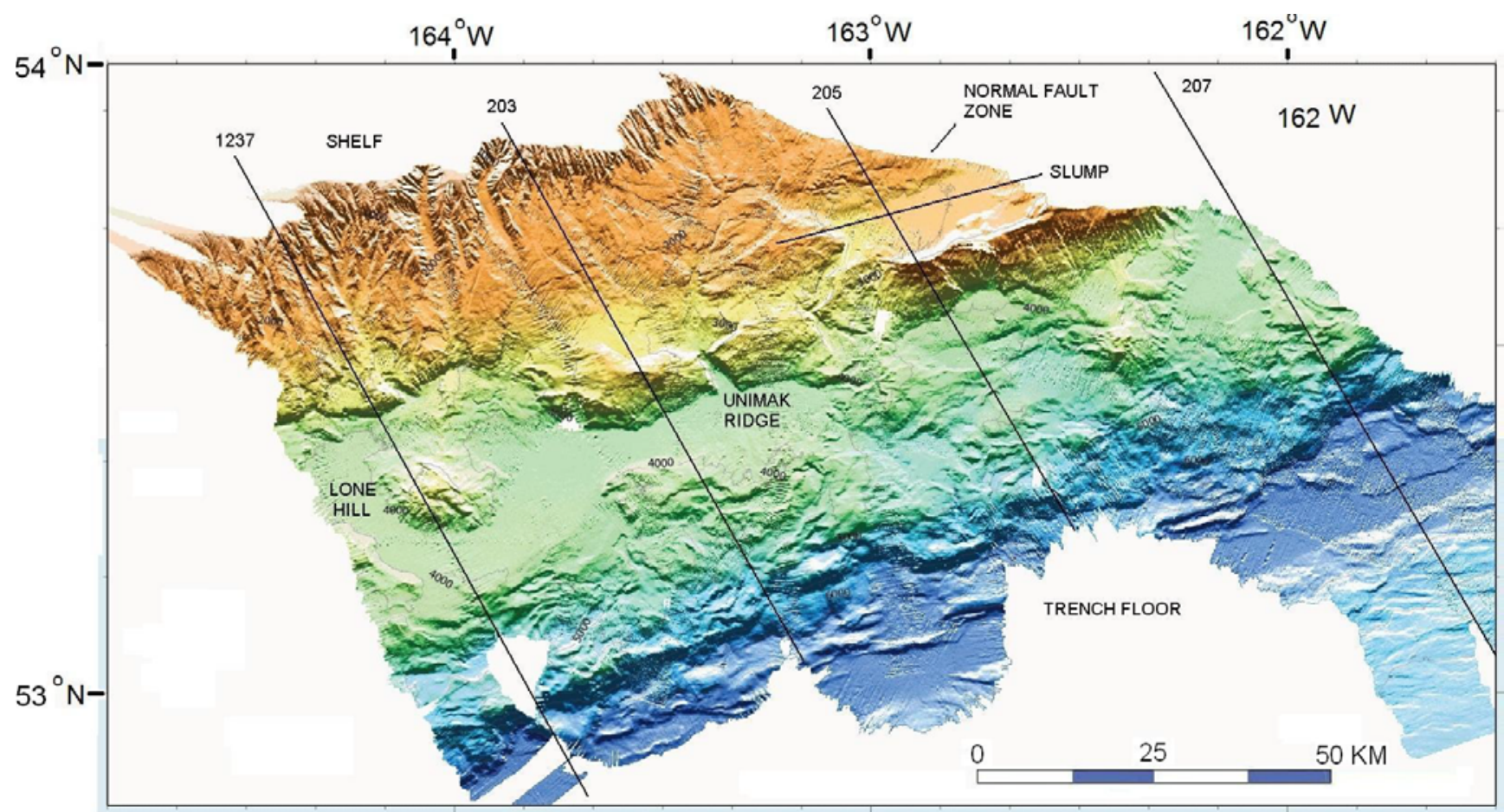

Figure 2. Multibeam bathymetry acquired with RV Ravelle (Rathburn and others, 2009) showing slope morphology in greater detail. Normal faults upslope of Unimak Ridge and a large slump are visible. The size of the slump is comparable to that of Lone Hill. Seismic lines annotated as in figure 1. Color scheme: Red is shallow beginning at roughly 1,000 meters and dark blue is deeper than 6,000 meters.

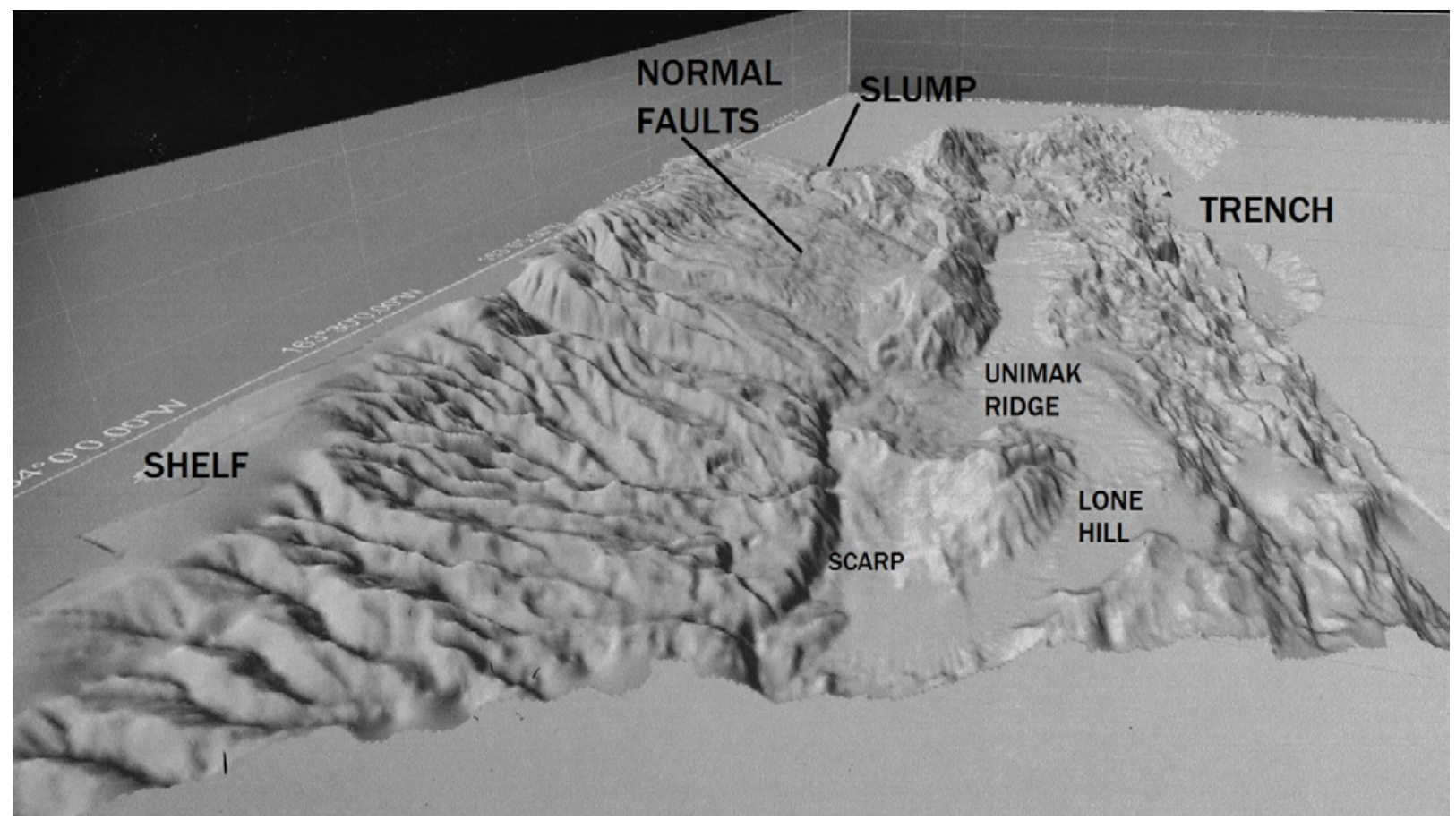

Figure 3. Perspective diagram of the bathymetry in figure 2 looking along the margin toward the northeast. The morphology of a Lone Hill slide and the features associated with it become more apparent. 


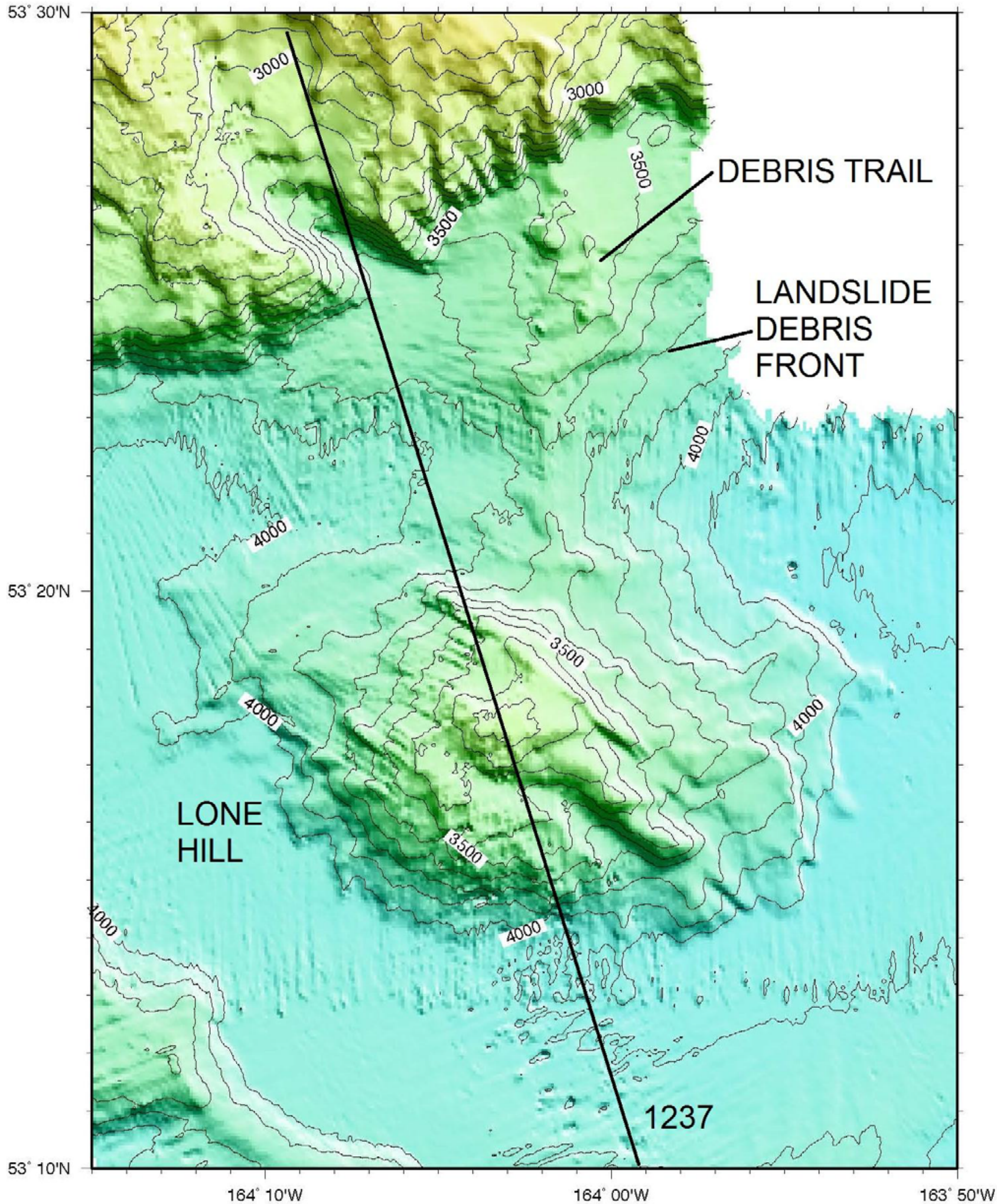

Figure 4. Large-scale bathymetry of Lone Hill from the RV Ravelle survey showing the escarpment from which it probably derived. Note that "caterpillar tracks" caused by incomplete correction of the multibeam-instrument gyros show the direction of ships tracks. The 30 degree angle between hill structure and the seismic Line 1237 (in black) complicated resolution of the seismic image. Color scheme: Red is shallow beginning at roughly 1,000 meters and dark blue is deeper than 6,000 meters. 